\title{
A HAJLÉKTALAN EMBEREK EGÉSZSÉGE
}

\section{Rákosy Zsuzsa - Szeitl Blanka}

\section{ÖSSZEFOGLALÓ}

Annak ellenére, hogy a hajléktalan emberek száma hazánkban is növekszik, egészségi állapotukról nagyon kevés információ állt a rendelkezésünkre. Kutatásunkban 453 hajléktalanellátó rendszert igénybe vevő ember kérdőíves adatait hasonlítottuk össze az Európai lakossági egészségfelmérés 2014, hajléktalan populáció nem és kor szerinti megoszlását tükröző, standardizált eredményeivel, az átlagpopuláció, valamint az átlagpopuláció alsó jövedelmi ötödébe tartozó emberek és a hajléktalanként élők egészségiállapot-különbségeinek azonosítása céljából.

Míg az átlagpopulációban a legalább egy krónikus nem fertőző betegséggel bírók aránya 50\% volt, az alsó jövedelmi ötödbe tartozóknál 59, addig a hajléktalanok körében jóval magasabb, 79\% volt, ennek ellenére a hajléktalanok háziorvoshoz fordulási gyakorisága (38\%) messze elmaradt a másik két populációhoz képest (76, 78\%). Tovább rontja a helyzetet körükben a dohányzók rendkivül magas aránya (82\%), valamint a referencia populációkhoz képest a nagyivók (29\%) és az alultápláltak (4\%) magasabb aránya.

Adataink alapján az egészségügyi ellátáshoz való hozzáférés javítása, valamint a célzott egészségfejlesztési programok, kulcsfontosságúak a hajléktalan emberek egészségi állapotának javítása érdekében, ami további esélyt jelenthet a társadalomba való visszailleszkedésükhöz.

Tárgyszavak: hajléktalan ember, egészségi állapot, egészségmagatartás

Rákosy Zsuzsa, PTE ÁOK Orvosi Népegészségtani Intézet

E-mail: zsuzsa.rakosy@aok.pte.hu

Szeitl Blanka, TÁRKI Társadalomkutatási Intézet Zrt.

E-mail: blanka.szeitl@gmail.com 


\section{BEVEZETÉS}

A hajléktalanság az anyagi nélkülözés extrém szélsőséges formája, amely egyéni és társadalmi tényezők összetett kölcsönhatásának eredője (Busch-Geertsema et al. 2010). A hajléktalanná válás okai között szereplő egyéni faktorok közül kiemelendő a szegénység, a családi problémák (elsősorban a válás és a családon belüli erőszak), továbbá a mentális egészségi problémák, a drog- és alkoholfüggőség, míg társadalmi szempontból a legfontosabb determinánsok a munkanélküliség, a magas ingatlanárak, az eladósodás, az alacsony fizetések és a munkahelyek számának csökkenése (Thompson et al. 2013, Patterson et al. 2012, van den Bree et al. 2009, Burt et al. 2001).

A hajléktalan emberek a sztereotípiákkal ellentétben nem alkotnak homogén csoportot, a nemzetközi tipológia (az ETHOS, azaz „A hajléktalanság és a lakhatásból való kirekesztettség európai tipológiája") a lakhatás fizikai, szociális és jogi dimenziói mentén négy csoportot különböztet meg. Minden szempontból leghátrányosabb csoportot a hajléktalanokon belül a fedél nélküliek képezik, azok az emberek, akik közterületeken, illetve krízisszállókon élnek. Lakástalanoknak hívjuk azokat, akik átmenetileg intézményi körülmények között élnek, mint például átmeneti szállásokon, anyaotthonokban, bevándorlók menedékhelyén stb. Bizonytalan lakáshelyzetben lévők átmenetileg családnál, barátnál vagy illegálisan elfoglalt ingatlanokban, míg az elégtelen lakáskörülmények között élők lakóhelyként alkalmatlan bódékban, kalibákban élnek (FEANTSA 2017).

Nehéz megbecsülni, hogy pontosan hányan élnek hajléktalan létbe kényszerülve ma hazánkban, adataink elsősorban a hajléktalanellátó intézményeket igénybe vevő emberekről vannak, az utcán, a bizonytalan lakáshelyzetben lévők és elégtelen lakáskörülmények között élők számáról nagyon keveset tudunk. A becslést tovább nehezíti, hogy a hajléktalan lét nem egy állandó állapot, folyamatos az átmenet a hajléktalanság különböző dimenziói között. A fix időpontbéli adatfelvétel általában túlbecsüli a krónikus, hosszabb ideje hajléktalanságban élő emberek számát, és alábecsüli az átmenetileg rövid ideig hajléktalan létbe kényszerültekét. Ennek ellenére elmondható, hogy a hajléktalanok száma világszerte folyamatosan emelkedő tendenciát mutat. Egy 2014-es tanulmány alapján abban az évben az Európai Unió területén 400 000, az Egyesült Államokban több mint 600000 egyén töltött legalább egy éjszakát hajléktalanként (Fazel et al. 2014). Hazánkban 1999 óta minden év február 3-án a „Február Harmadika Munkacsoport” vezetésével adatfelvétel valósul meg a hajléktalan szállókon és az utcai szolgálatok által ellátottak körében, amelynek célja, hogy átfogó képet nyújtson a hajléktalan helyzetben 
lévők életkörülményeiről a hajléktalan ellátás fejlesztése érdekében, továbbá országos eredményeket szolgáltasson azoknak az embereknek a számáról, akik a hajléktalan ellátást igénybe veszik a felmérés napján. A legfrissebb, 2018-as felmérésben 8650 hajléktalan ember vett részt (Gurály et al. 2018). Egy évre vonatkoztatott számok viszonylatában a legfrissebb adatokat a Győri Péter által elkészített Hajléktalanügyi országjelentés közli 2013-ból a Kenyszi (Központi Elektronikus Nyilvántartás a Szolgáltatást Igénybevevőkről) nyilvántartási rendszere alapján. A „2013-ban a hajléktalanellátás igénybe vevőjeként összesen 37377 embert regisztráltak - az utcai szolgálatok által ellátott emberek nélkül. Az éjjeli menedékhelyeket 2013-ban összesen 13360 ember vette igénybe, az átmeneti szállókat 9216 ember, a nappali melegedőket 33026 ember kereste fel az év során, ez megfelel egy magyar kis- vagy közepes város lakosságának" (Győri 2013).

Ismert tény, hogy az anyagi depriváció szorosan összefügg az egészségi állapottal. Népegészségügyi szempontból különösen aggasztó ezeknek az embereknek a magas mortalitása és morbiditása az átlagpopulációhoz képest. A megbetegedések közül különösen az életmódjukból és életkörülményeikből adódó egészségproblémák érintik őket: a balesetekből származó sérülések, a pszichiátriai betegségek, a fertőző betegségek és a felgyorsult öregedéssel párhuzamosan megjelenő krónikus nem fertőző betegségek. Amíg egyes egészségi problémák, mint például a pszichiátriai betegségek, hajléktalansághoz vezethetnek, mások viszont a hajléktalanság következményeként jelenhetnek meg. A durva környezeti körülmények, a zsúfolt hajléktalanszállók, a rossz higiénés viszonyok, az alultápláltság hozzájárulnak az egészségi állapotuk megromlásához, amit tovább súlyosbít az egészségügyi ellátáshoz való korlátozott hozzáférésük (Hwang et al. 2010, Baggett et al. 2010, Canavan et al. 2012).

Egészségi állapotuk javitása egyaránt kulcsfontosságú a saját és a társadalom szempontjából is, hiszen leromlott egészségi állapotuk nagy terhet ró mind az egyénre, mind az egészségügyi ellátórendszerre. Célzott intervenció tervezésére és kivitelezésére viszont csak abban az esetben nyilik mód, ha pontosan ismerjük a problémát. A magyar hajléktalanpopuláció egészségi állapotáról nagyon kevés információ állt a rendelkezésünkre, összesen két tanulmány - 1995-ben és 2007-ben - közölt erre vonatkozóan reprezentatív adatokat, továbbá magyarországi átlagpopulációval történő összehasonlító elemzésből származó eredmények csupán a budapesti hajléktalanpopulációra vonatkozóan érhetőek el 2002-ből (Oross 1995, Papp 2007, Gurály 2003). Az egészségüket meghatározó determinánsokról szintén keveset tudtunk, ezen belül a táplálkozási 
szokásaikról és tápláltsági állapotukról, amelyek döntően befolyásolják az egészségi állapotot, pedig semmilyen adatunk nem volt. Ez alapozta meg az általunk 2015-től elkezdett „A hajléktalanok tápláltsági állapotának és táplálkozási szokásainak felmérése" című projektet, amely áttekintést nyújt a hajléktalanellátó rendszert igénybe vevő emberek élelmiszer- és tápanyagbeviteléről, meghatározza a fő egészségi és táplálkozási problémáikat. Ennek keretében 2015-ben 453, a hajléktalanellátó intézményeket igénybe vevő ember egészségi, szociális és tápláltsági állapotának, táplálkozási szokásainak felmérése valósult meg kérdőíves, antropometriai és vérminta alapú analízissel Pécs, Debrecen és Budapest hajléktalanellátó intézményeiben.

A felmérésünk adatait összehasonlítva az ELEF2014-es felmérés eredményeivel lehetőség nyílik az átlagpopuláció, valamint az átlagpopuláció alsó jövedelmi ötödébe tartozó emberek és a hajléktalanként élők egészségi állapotában mutatkozó különbségek azonosítására a vélt egészséggel és a krónikus betegségekkel jellemezve, valamint az egészségmagatartás egyes jellemzőinek, úgyis mint a dohányzás, táplálkozási és alkoholfogyasztási szokások összehasonlítására. Terjedelmi korlátok miatt ez az elemzés nem tér ki a hajléktalanság különböző csoportjaiba tartozó emberek egészségi állapota, illetve egészségmagatartása közötti különbségekre.

A kutatásból származó adatok alapot szolgáltatnak a hajléktalan emberek egészségének javítását célzó prevenciós programok kialakításához, amelyek a hajléktalan lét komplexitásának tükrében csak olyan koordinált projekt keretében valósulhatnak meg, amely figyelembe veszi a hajléktalanság speciális jellemzőit. Eredményeink segítséget jelenthetnek a hazai hajléktalanellátás specifikus reformjához, interszektorális együttműködések kialakításához, amelyekre igen nagy szükség van a hajléktalanság összetett, soktényezős okai és következményei miatt, továbbá alapot szolgáltathatnak a hajléktalan emberek egészségének javításához szükséges kormányzati intézkedések kidolgozásához is. A hajléktalan emberek egészségi állapotának és egészségmagatartásának javítása kulcsszerepet játszhat társadalmi visszailleszkedésükben.

\section{MÓDSZEREK}

Az elemzés az ELEF2014 és a „Hajléktalanok tápláltsági állapotának és táplálkozási szokásainak felmérése” adatainak felhasználásával készült. Az adatfelvétel Pécsett a TÁMASZ Alapítvány hajléktalanellátó intézményeiben, Debrecenben a 
ReFoMix Nonprofit Közhasznú Kft. nappali melegedőjében, éjszakai menedékhelyén és átmeneti szállásain, az Ökomenikus Segélyszervezet nappali melegedőjében, Budapesten a Máltai Szeretetszolgálat nappali melegedőiben, éjszakai menedékhelyein és fertőtlenítő fürdőjében összesen 453, 18 év feletti fő bevonásával 2015. január 1. és április 30. közötti időszakban zajlott. Az intézmények kiválasztása ad hoc módon történt, mert ezekkel az intézményekkel sikerült kutatási együttműködést kialakitani. Semmilyen, a hajléktalanok egészségével kapcsolatos jellemző nem motiválta a kiválasztásukat, ily módon a vizsgálat szempontjából véletlenszerünek tekinthető a kiválasztásuk. A felmérésbe az adott intézményben a kérdőívfelvételkor jelen lévő, a vizsgálatban önkéntesen részt venni hajlandó személyeket vontuk be. Győri Péter 2013-as adatai a legfrissebb publikált eredmények a hazai hajléktalanellátást éves szinten igénybe vevők számáról (33 026 fő), ehhez mérten a 453 fős hajléktalan-adatbázis nagyjából 1\%-os mintának felel meg (Győri 2013). Az adott napon ellátást igénybe vevők számához képest (2018. február 3-ai adatfelvétel: 8650 fő) ez körülbelül 5\%-os mintának felel meg (Gurály et al. 2018).

A két felmérés a célpopuláció szempontjából tulajdonképpen kiegészitője egymásnak: míg az ELEF2014 - mint más lakossági adatfelvételek - nem foglalja magában a hajléktalanpopulációt (lakcím nélküliek), úgy a hajléktalanok felmérése nem tartalmaz olyan egyéneket, akiket a lakossági adatfelvétel elérhet. A két felmérés résztvevői olyan alapvető demográfiai jellemzők szerint is különböznek, amelyek nyilvánvalóan komoly befolyással bírnak az általunk elemzett táplálkozási és egészségi állapotra. Ilyen a kérdezett neme, kora, illetve jövedelmi helyzete. Az életkor és a nem együttes eloszlásából származó különbséget az 1. táblázat szemlélteti.

1. táblázat: A vizsgált populációk megoszlása nem és életkor szerint Age and sex distribution of the studied population

\begin{tabular}{|c|c|c|c|c|c|c|c|c|}
\hline \multirow{3}{*}{ Populáció } & \multirow{3}{*}{ Nem } & \multicolumn{6}{|c|}{ Korcsoport } & \multirow{3}{*}{ Együtt } \\
\hline & & $18-29$ & $30-39$ & $40-49$ & $50-59$ & $60-69$ & $70+$ & \\
\hline & & \multicolumn{6}{|c|}{ éves } & \\
\hline \multirow[t]{2}{*}{ Hajléktalanok } & Férfi & 4,1 & 12,3 & 20,4 & 35,4 & 25,6 & 2,2 & 100,0 \\
\hline & Nő & 7,0 & 9,3 & 24,4 & 39,5 & 17,4 & 2,3 & 100,0 \\
\hline \multirow[t]{2}{*}{ ELEF2014 } & Férfi & 21,8 & 17,7 & 17,6 & 15,8 & 15,3 & 11,8 & 100,0 \\
\hline & Nő & 16,6 & 16,8 & 16,9 & 15,8 & 16,1 & 17,8 & 100,0 \\
\hline
\end{tabular}


A számottevő eltérés miatt az ELEF becsléseit nem és kor szerint standardizáltuk úgy, hogy a két dimenzió szerint, az 1. táblázatban szemléltetett bontásban a hajléktalanpopuláció megoszlásait tükrözze. Azaz csak azokat a korosztályokat vettük figyelembe az ELEF mintájából, amelyek a hajléktalanpopulációban is előfordultak (minimum év-maximum év), és ezen belül olyan korosztályos súlyokat használtunk, mint amilyen a nemek szerinti korcsoportok részaránya volt a hajléktalanok mintáján belül. A két felmérés adatállományát ezután integráltuk, és az elemzéseket ezen együttes és speciális összetétel szerint súlyozott adatbázis alapján végeztük el. A jövedelem azért nem szerepel a súlyozáshoz felhasznált változók között, mert az ELEF-adatok esetében nem érhető el a jövedelem pontos összege (csak a kvintilis), így a súlyok beállítása eszerint nem lehetséges. A jövedelmi különbségek torzulása miatt minden alkalommal törekedtünk arra, hogy a hajléktalanpopuláció jellemzőit ne csak a súlyozott, teljes ELEF-adatokhoz hasonlítsuk, hanem a teljes populáció legalsó jövedelmi ötödébe tartozókkal külön is összevessük. Az elemzés nem tartalmaz kor és nemek szerinti bontásból származó adatokat, mivel a hajléktalanpopuláció jelentős százalékát középkorú férfiak alkotják.

Az elemzésben khi-négyzet próbát alkalmaztunk 5\%-os szignifikanciaszinttel. A hajléktalanok körében mindegyik vizsgált jellemző eloszlása statisztikailag szignifikánsan különbözött az átlagpopuláció és annak alsó jövedelmi ötödének eloszlásától.

Felmérésekben a prevalencia becslések hibahatár maximumaként a standard hiba kétszeresét szokták megadni. Nagy minták esetén várhatóan a felmérésből számított becsléseknek 95\%-a közelebb lesz a becsülni kívánt populációs paraméterhez, mint a hibahatár. A maximális hibahatárt a következő képlettel határoztuk meg:

$$
\frac{0,98}{\sqrt{n}}
$$

ahol $n$ a mintanagyságot jelöli. Esetünkben a hibahatár maximuma a hajléktalanokra vonatkozó becslések esetében $\pm 4,6 \%$ az átlagpopulációra vonatkozó becslések esetében $\pm 1,3 \%$, az átlagpopuláció alsó jövedelmi ötödére vonatkozó becslések esetében $\pm 2,5 \%$. 


\section{ELEMZETT VÁLTOZÓK}

Minden elemzett ELEF2014 változónál a „Hajléktalanok tápláltsági állapotának és táplálkozási szokásainak felmérése” kérdőív kategóriáival összevethető kategóriákat hoztunk létre.

\section{A vizsgált társadalmi-gazdasági tényezők meghatározása}

Az iskolázottság esetében az alábbi kategóriákat használtuk:

- kevesebb mint 8 általános iskolai osztály,

- 8 általános,

- szakmunkás,

- középfokú,

- felsőfokú.

A gazdasági aktivitást az alábbiak szerint kategorizáltuk:

- nem dolgozik,

- dolgozik,

- nyugdíjas.

A családi állapotot az alábbiak szerint kategorizáltuk:

- házas vagy élettárssal él,

- hajadon/nőtlen,

- özvegy,

- elvált.

\section{Az egészségi állapot jellemzése}

Az egészségi állapot jellemzésére a vélt egészséget és a krónikus betegségek változót használtuk.

A vélt egészséget a következő kérdés alapján képeztük:

„Milyen az Ön egészsége általában?”

- jó

- kielégítő

- rossz

- nem tudja 
Az eredetileg meglévő „nagyon jó”, ,jó”, valamint a „rossz” és „nagyon rossz” kategóriákat összevontuk jó, illetve rossz elnevezés alatt. Habár az ELEF2014 kérdőive lehetőséget adott a „nem tudja” válaszra, ám egyetlen válaszadó sem élt ezzel, mégis benne hagytuk az elemzésben a hajléktalanpopulációra vonatkozó érdekes információtartalma miatt.

A krónikus nem fertőző betegségek prevalenciájának meghatározásához „van”, illetve „nincs” kategóriákat használtuk az ELEF2014 15. kérdésének megfelelően: „Van-e Önnek valamilyen krónikus betegsége vagy olyan egészségi problémája, ami legalább 6 hónapja tart, vagy előreláthatólag legalább 6 hónapig fog tartani?"

Az elemzésben terjedelmi korlátok miatt nem tértünk ki a nagyobb betegségcsoportok populációs szintű megoszlásának ismertetésére.

\section{Az egészségdeterminánsok jellemzése}

Az egészségdeterminánsok közül a tápláltsági állapot, az alkoholfogyasztási és a dohányzási szokások, valamint az orvoshoz fordulási gyakoriságváltozókat használtuk.

A tápláltsági állapot meghatározására, a testtömegindexet alkalmaztuk. Kiszámításához a kilogrammban mért testtömeget osztani kell a magasság méterben mért négyzetével. Az adatokat az ELEF2014-kérdőív 74. „Milyen magas Ön cipő nélkül?” és a 75. „Mekkora a testsúlya ruha és cipő nélkül?” kérdéseire adott válaszokból számítottuk. A hajléktalan emberek esetében ezek az értékek testösszetétel-mérővel kerültek felmérésre. Az eredmények alapján a következő, a szakirodalomban használatos kategóriákat képeztük (WHO 1995):

- sovány: < 18,50,

- normál testsúly: 18,50 - 24,99,

- túlsúlyos: 25,00 - 29,99,

- elhízott: $\geq 30,00$.

Az alkoholfogyasztási gyakoriság meghatározására az alábbi kategóriákat használtuk az ELEF2014-kérdőív 105-ös „Az elmúlt 12 hónapban milyen gyakran fogyasztott Ön alkohol tartalmú italt (mint például sör, bor, pezsgő, pálinka, vodka, rum, whisky, koktél, likőr, alkoholos üdítő, házilag előállított alkohol...)?” és a 106-os „Egy átlagos héten milyen és mennyi italt fogyaszt az egyes napokon?” kérdése alapján: 
- nagyivó,

- mértékletes ivó,

- ritkán fogyaszt,

- absztinens.

A kategóriákat az irodalomban használatos kritériumrendszer alapján határoztuk meg.

- „Nagyivónak neveztük azokat a nőket, akik a kérdezést megelőző héten összesen több mint 7, illetve azokat a férfiakat, akik több mint 14 egységnyi alkoholt fogyasztottak (egy ital/alkoholegység egy korsó sörnek, 2 dl bornak vagy 0,5 cl röviditalnak felel meg, azaz 1 dl sör 0,2 italnak, 1 dl bor 0,5 italnak és 1 cl rövidital 0,2 italnak számít), továbbá azokat, akik naponta egyszer vagy többször 6 egység vagy ennél több italt fogyasztanak.

- Mértékletes alkoholfogyasztóknak tekintettük azokat, akik legalább heti gyakorisággal fogyasztottak alkoholt, de nem minősültek nagyivónak.

- Alkoholt ritkán fogyasztóknak neveztük azokat, akik szoktak szeszes italt fogyasztani, de hetinél ritkább gyakorisággal.

- Absztinensnek neveztük azokat, akik saját bevallásuk szerint egyáltalán nem szoktak alkoholtartalmú italokat inni (Európai lakossági egészségfelmérés 2014).

A dohányzási szokások jellemzéséhez az ELEF2014-kérdőív 92. kérdését használtuk fel: „Kérem, mondja meg, melyik állítás illik Önre a legjobban a dohányzással kapcsolatban!” A ,jelenleg dohányzom”, „kevesebb mint egy éve abbahagytam a dohányzást”, „már több mint egy éve leszoktam a dohányzásról” és „sohasem dohányoztam” ELEF2014-es kategóriákból a hajléktalan-adatbázissal összevetve az alábbi kategóriákat képeztük:

- nem, soha nem dohányzott,

- nem, már leszokott,

- jelenleg dohányzik.

A jelenleg dohányzók körében a 96-os kérdésre adott válaszokat használtuk fel, ami a naponta elszívott cigaretta mennyiségére kérdez rá. Ennek alapján az alábbi kategóriákat alkottuk:

- 0-5 szál,

- 6-10 szál,

- 11-15 szál,

- 16-20 szál,

- >20 szál. 
Orvoshoz fordulási gyakoriságot a 49., „Mikor találkozott Ön utoljára háziorvosával saját egészsége érdekében?” kérdés alapján kategorizáltuk:

- az elmúlt 12 hónapban,

- 12 hónapja vagy régebben,

- soha.

\section{EREDMÉNYEK}

\section{A célpopulációk összetétele a vizsgálatba bevont társadalmi gazdasági tényezők szerint}

Az elemzés a hajléktalanpopuláció esetében 453, az ELEF2014-nél 5826, az alsó jövedelmi ötödbe tartozóknál pedig 1089 fős mintán alapult. A vizsgált hajléktalanpopuláció átlagéletkora 52 év (18-88,9 év), 81\%-uk férfi volt. A felmérésben részt vevő hajléktalan emberek 52\%-a több mint 5 éve, 32\%-uk kevesebb mint 5, de több mint 1 éve, 13\%-uk pedig 1 vagy kevesebb mint 1 éve élt hajléktalanként. Többségüknek (61\%-uknak) ez volt az első alkalom, hogy hajléktalansorba kényszerült, 21\%-uk már volt egyszer hajléktalan, míg 16\%-uknak ez már több mint a harmadik olyan alkalom volt, hogy hajléktalanként élt. Az ETHOS szerinti csoportosítás alapján a felmért populáció 27\%-a fedél nélküli, 51\%-a lakástalan, 11\%-a bizonytalan lakáshelyzetű, 11\%-a elégtelen lakáskörülmények között élő kategóriába tartozott.

A 2. táblázatban foglaltuk össze a célpopulációk iskolai végzettség szerinti megoszlását. Az adatokból jól látszik, hogy a jövedelem csökkenésével nő az alacsonyabb iskolai végzettségüek aránya, és ezzel párhuzamosan csökken a közép- és felsőfokú végzettséggel rendelkezők aránya. A felmérésben részt vevő hajléktalan emberek több mint felének (51\%) 8 általános iskola volt a legmagasabb iskolai végzettsége, az átlagpopulációban ez az arány jóval alacsonyabb, 13\% volt. Ugyanakkor az átlagpopuláció alsó jövedelmi ötödébe tartozó emberek között az átlagpopulációhoz képest közel háromszoros azoknak az aránya, akik csak általános iskolát végeztek. Középiskolai végzettséggel a hajléktalanok 6\%-a, felsőfokú végzettséggel 4\%-a rendelkezett. A középfokú végzettséggel rendelkezők száma emelkedő tendenciát mutat a jövedelmi viszonyok javulásával, míg a felsőfokú végzettségűek aránya az alsó jövedelmi 
Ötödbe tartozó személyeknél a hajléktalanok értékénél 1 százalékponttal alacsonyabb volt.

2. táblázat: A célpopulációk iskolai végzettség szerinti megoszlása

Educational status of the studied populations

\begin{tabular}{lccc}
\multicolumn{1}{c}{ Iskolai végzettség } & Átlagpopuláció & $\begin{array}{c}\text { Átlagpopuláció alsó } \\
\text { jövedelmi ötöd }\end{array}$ & Hajléktalan emberek \\
\hline Kevesebb mint 8 általános & 1,9 & 4,8 & 6,9 \\
8 általános & 13,3 & 30,6 & 51,4 \\
Szakmunkás & 47,9 & 50,5 & 31,2 \\
Középfokú & 18,0 & 11,0 & 6,2 \\
Felsőfokú & 18,9 & 3,1 & 4,2 \\
\hline
\end{tabular}

A gazdasági aktivitásra vonatkozó adatokat a 3. táblázat foglalja össze. A hajléktalanok körében nagyon magas (80\%) volt azoknak az aránya, akiknek nem volt munkájuk. A munkanélküliség az átlagpopuláció 18\%-át érintette, az alsó jövedelmi ötödbe tartozó emberek több mint egyharmada nem dolgozott. A nyugdíjasok aránya a hajléktalanok között 10\% alatti volt, míg a két referenciapopulációban ez az arány igen hasonló, 21 és 22\%.

3. táblázat: A célpopulációk gazdasági aktivitás szerinti megoszlása Economic activity of the studied populations

$(\%)$

\begin{tabular}{lccc} 
Gazdasági aktivitás & Átlagpopuláció & $\begin{array}{c}\text { Átlagpopuláció alsó } \\
\text { jövedelmi ötöd }\end{array}$ & Hajléktalan emberek \\
\hline Nem dolgozik & 17,5 & 36,9 & 80,1 \\
Dolgozik & 61,8 & 40,7 & 11,5 \\
Nyugdíjas & 20,7 & 22,4 & 8,4 \\
\hline
\end{tabular}

A hajléktalan emberek nagy része elvált (42\%), ez az arány közel négyszeres az átlagpopuláció értékeihez (12\%) képest, illetve közel tízszerese az alsó jövedelmi ötödbe tartozó emberek körében becsült prevalenciához (5\%) viszonyítva (4. táblázat). Az özvegy és a hajadon/nőtlen emberek aránya szintén magasabb volt a hajléktalan egyének körében, mint az átlagpopulációban. Amíg házas vagy élettársi kapcsolatban az átlagpopuláció 63\%-a, az alsó jövedelmi ötödbe tartozó emberek 78\%-a élt, addig a hajléktalanoknál ez az arány 12\% volt. 
4. táblázat: A célpopulációk családi állapot szerinti megoszlása

Marital status of the studied populations

$(\%)$

\begin{tabular}{lccc}
\multicolumn{1}{c}{ Családi állapot } & Átlagpopuláció & $\begin{array}{c}\text { Átlagpopuláció alsó } \\
\text { jövedelmi ötöd }\end{array}$ & Hajléktalan emberek \\
\hline Házas vagy élettárssal él & 62,7 & 77,5 & 11,6 \\
Hajadon/nőtlen & 20,5 & 15,2 & 39,4 \\
Özvegy & 5,3 & 2,7 & 6,9 \\
Elvált & 11,5 & 4,7 & 42,1 \\
\hline
\end{tabular}

\section{Az egészségi állapot jellemzőinek becsült populációs megoszlása: vélt egészség, a krónikus nem fertőző betegségek és az orvoshoz fordulási gyakoriság}

Az elemzett három populáció között a társadalmi-gazdasági viszonyok rosszabbodásával jelentősen csökkent azoknak az embereknek az aránya, akik az egészségi állapotukat jónak ítélték meg (5. táblázat). Míg az átlagpopuláció több mint a fele jónak vélte egészségi állapotát, az alsó jövedelmi ötödbe tartozók 37\%-a, a hajléktalan emberek csupán 5\%-a gondolta ezt. Az egészségüket rossznak vélők aránya a hajléktalan emberek körében volt a legmagasabb (33\%). Említésre méltó, hogy a hajléktalanok több mint tizede az egészségi állapot becslésére irányuló kérdésre nem tudott választ adni.

5. táblázat: A célpopulációk vélt egészség szerinti megoszlása

Self-reported health status of the studied populations

$(\%)$

\begin{tabular}{lccc} 
Vélt egészség & Átlagpopuláció & $\begin{array}{c}\text { Átlagpopuláció alsó } \\
\text { jövedelmi ötöd }\end{array}$ & Hajléktalan emberek \\
\hline Nem tudja & 0,0 & 0,0 & 11,1 \\
Rossz & 12,7 & 26,9 & 32,7 \\
Kielégítő & 30,9 & 36,7 & 51,1 \\
Jó & 56,4 & 36,4 & 5,1 \\
\hline
\end{tabular}

Míg az átlagpopulációban a legalább egy krónikus nem fertőző betegséggel rendelkezők aránya 50\% volt, addig az alsó jövedelmi ötödbe tartozóknál 59\%, a hajléktalanok körében pedig jóval magasabb,79\% volt.

A vélt egészség szoros összefüggést mutatott a krónikus nem fertőző betegségek előfordulásával. A legalább egy krónikus nem fertőző betegséggel élők közül az átlagpopulációban 24, az alsó jövedelmi ötödbe tartozó 
populációban 41\% volt azoknak az aránya, akik rossznak, továbbá 44 és 43\% azoké, akik kielégítőnek itélték meg az egészségüket. A krónikus betegségben szenvedő hajléktalan emberek 37\%-a gondolta rossznak, és 47\%-a vélte kielégítőnek az egészségét. A jó vélt egészségűek aránya a felmért hajléktalanpopulációban volt a legalacsonyabb (5\%).

Annak ellenére, hogy a felmérésben részt vevő hajléktalan emberek 79\%-ának volt valamilyen krónikus betegsége, a felmérést megelőző egy évben csupán 38\%-uk, ennél régebben 52\%-uk járt háziorvosnál, 10\%-uk pedig még panaszok esetén sem fordult a hajléktalanellátásban dolgozó háziorvosokhoz. Ez utóbbi arány több mint tizenötszöröse az átlagpopulációra jellemzőnek (1. ábra). A háziorvoshoz fordulási gyakoriság a két referenciapopulációban hasonló, a felmérést megelőző 12 hónapon belül több mint 75\%-uk kereste fel háziorvosát.

\section{1. ábra: A háziorvoshoz fordulási gyakoriság a vizsgált populációkban}

Frequency of visiting general practitioners

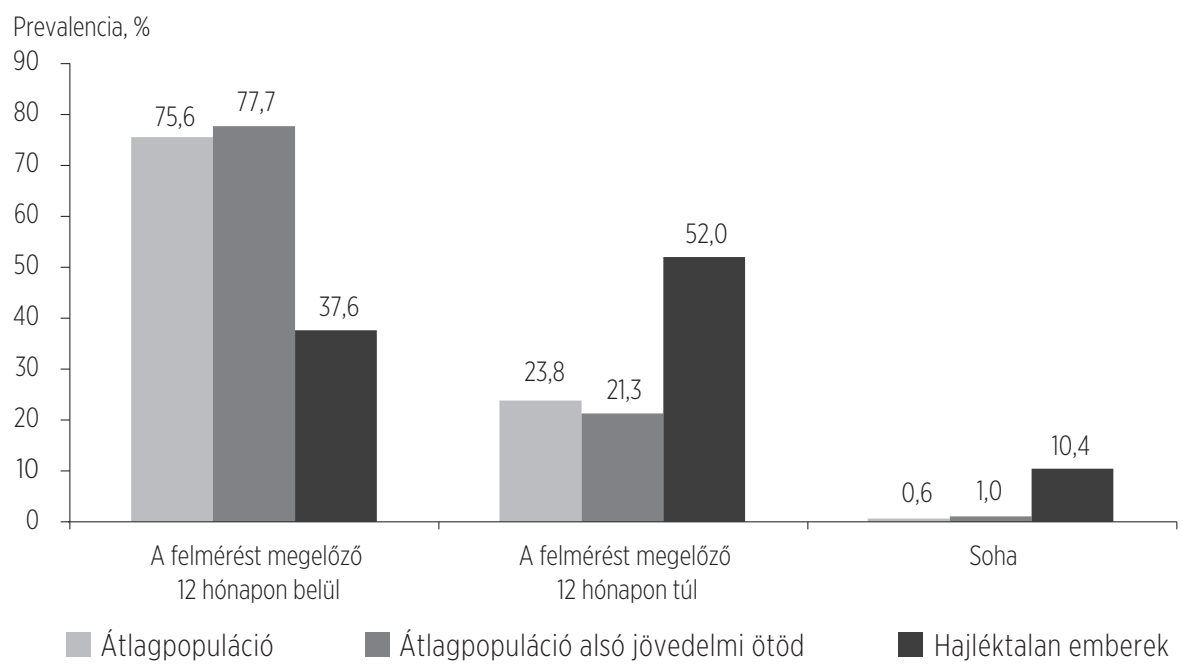

Ha külön megvizsgáljuk azoknak az embereknek a háziorvoshoz fordulási szokásait, akiknek volt legalább egy krónikus betegsége, még inkább szembetűnik az átlagpopuláció és a hajléktalanpopuláció közötti különbség (6. táblázat). Az átlagpopuláció 91\%-a, az átlagpopuláció alsó jövedelmi ötödébe tartozók 93\%-a járt egy éven belül a háziorvosnál azok közül, akiknek volt valamilyen krónikus betegsége. A hajléktalan emberek esetében ez az arány jóval kisebb, 
a krónikus betegséggel rendelkezők csupán 41\%-a fordult egy éven belül orvoshoz, 7\%-uk azonban a betegség meglététől függetlenül sem kereste fel háziorvosát.

6. táblázat: A háziorvoshoz fordulási gyakoriság a krónikus betegségben szenvedők körében Frequency of visiting general practitioners among people with chronic disease

\begin{tabular}{lccc}
$\begin{array}{l}\text { Orvoshoz fordulási } \\
\text { gyakoriság }\end{array}$ & Átlagpopuláció & $\begin{array}{c}\text { Átlagpopuláció alsó } \\
\text { jövedelmi ötöd }\end{array}$ & Hajléktalan emberek \\
\hline $\begin{array}{c}\text { A felmérést megelőző } 12 \\
\text { hónapon belül }\end{array}$ & 91,4 & 92,8 & 41,4 \\
$\begin{array}{c}\text { A felmérést megelőző } 12 \\
\text { hónapon túl } \\
\text { Soha }\end{array}$ & 8,4 & 7,2 & 51,3 \\
\end{tabular}

A hazai átlag és hajléktalanpopulációkban a krónikus betegségek prevalenciájában és a háziorvoshoz fordulási gyakoriságban mutatkozó nagy különbségek nagyon aggasztóak a hajléktalan emberek egészségét illetően. További kutatások szükségességére hívják fel a figyelmet, annak kiderítésére, hogy milyen okok állnak annak a hátterében, hogy a hajléktalanok kevesebb mint fele részesül csak háziorvosi ellátásban, annak ellenére, hogy az adott város hajléktalanellátó intézményei rendelkeznek egészségügyi központtal, ahol rendszeresen müködik háziorvosi szolgálat. E kérdések tisztázása, a beavatkozási pontok azonosítása kulcsfontosságú lehet a hajléktalan emberek egészségi állapotának javítása érdekében.

\section{Tápláltsági állapot}

A táplálék minősége és mennyisége alapvetően befolyásolja szervezetünk működését és testünk tömegét. A megfelelő mennyiségű és minőségű táplálékbevitel segít megakadályozni az alultápláltság, valamint különböző hiánybetegségek kialakulását, emellett szerepet játszik számos akut és krónikus betegség megelőzésében (Schulze et al. 2018). Irodalmi adatok alapján a normál tápláltsági állapotba tartozó emberek körében a legalacsonyabb a korai halálozás kockázata, míg a testtömegindex növekedésével nő a szív- és érrendszeri, valamint a daganatos és anyagcsere-betegségek miatti korai halálozás kockázata (Abdelaal et al. 2017). 
A táplálkozás sok más tényező mellett folyamatos kihívást jelent a hajléktalan emberek számára, a nem megfelelő táplálkozás nagymértékben hozzájárulhat az egészségi állapotuk romlásához. Kutatásunk a magyarországi hajléktalanok körében elvégzett első olyan felmérés, amely többek között adatokat szolgáltat a hajléktalanellátó rendszert igénybe vevő emberek tápláltsági állapotáról is.

A társadalmi sztereotípiák, a média és egyes korai tanulmányok (Gelberg 1995) a hajléktalanokat soványként írják le. Ezzel szemben, a felmérésben részt vevő hajléktalanok 35\%-a túlsúlyos, illetve elhízott volt a testtömegindex értékeik alapján (7. táblázat).

7. táblázat: A testtömegindex megoszlása a vizsgált populációkban Distribution of body mass index in the studied populations

\begin{tabular}{lccc} 
Testtömeg-index & Átlagpopuláció & $\begin{array}{c}\text { Átlagpopuláció alsó } \\
\text { jövedelmi ötöd }\end{array}$ & Hajléktalan emberek \\
\hline Alultáplált & 0,8 & 1,8 & 4,1 \\
Normál & 31,1 & 36,3 & 60,9 \\
Túlsúlyos & 41,0 & 35,5 & 21,7 \\
Elhízott & 27,1 & 26,5 & 13,3
\end{tabular}

Az ELEF2014 standardizált adataival összehasonlítva azonban megállapitható, hogy a hajléktalanok körében az elhízás és túlsúly jóval alacsonyabb gyakorisággal fordul elő az átlagpopulációhoz (68\%), illetve az alsó jövedelmi ötödbe tartozó emberekhez (63\%) viszonyítva (7. táblázat). Meg kell említeni, hogy az alultápláltság bár alacsony százalékban (4\%) volt jelen a hajléktalanpopulációban, ám még így is ötszöröse az átlagpopulációra jellemző prevalenciának (0,8\%). A normál testtömegindexszel rendelkezők aránya a három vizsgált populációban a legmagasabb a hajléktalanoknál volt (61\%), ez a kategória az átlagpopulációban 31, az alsó jövedelmi ötödbe tartozó embereknél 36\%-os gyakorisággal fordult elő.

Nemzetközi és hazai kutatások igazolják, hogy az egészségtelen táplálkozásból és a mozgásszegény életmódból adódó túlsúly, illetve elhízás a Föld összlakosságát tekintve a legjelentősebb rizikófaktorrá lépett elő a krónikus nem fertőző betegségek kialakulásában (WHO 2000). A 2. ábra egy érdekes összefüggésre hívja fel a figyelmünket a krónikus betegségben szenvedők körében előforduló túlsúly és az elhízás gyakoriságát illetően. 
2. ábra: A testtömegindex megoszlása a krónikus betegek között

Distribution of body mass index among people with chronic disease

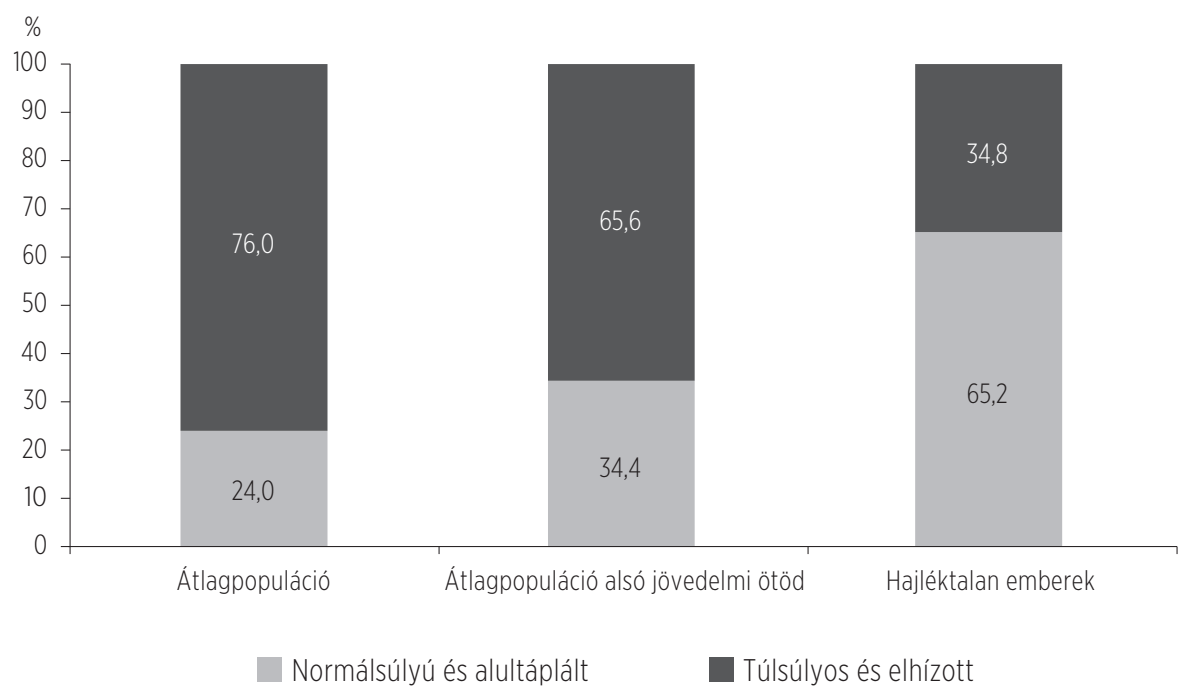

Az irodalmi adatoknak megfelelően az átlagpopulációban a krónikus betegségben szenvedők jelentős része (76\%) túlsúlyos, illetve elhízott (2. ábra). Az alsó jövedelmi ötödben az elhízott és a túlsúlyos egyének összesitett prevalenciája (62\%) az átlagpopulációs értékhez (68\%) (7. táblázat) hasonló, viszont az alsó jövedelmi ötöd krónikus betegei között 10 százalékponttal alacsonyabb a 25 feletti testtömegindexszel rendelkezők aránya az átlagpopulációhoz képest. A hajléktalan embereknél ez az arány jóval alacsonyabb, 35\% volt.

\section{Dohányzási és alkoholfogyasztási szokások}

A dohányzás egészségkárositó hatásai jól ismertek. A dohányzás komoly népegészségügyi probléma, a dohányfüst nikotin, kátrány és szénmonoxid tartalma jelentősen növeli többek között a szív- és érrendszeri betegségek, a tüdő-, gége- és hólyagdaganat kialakulásának kockázatát. Folyamatos kihívás a nemdohányzók védelme a levegőszennyezés mérséklése szempontjából, továbbá nagy terhet ró az egészségügyi ellátórendszer különböző területeire is.

A hajléktalan emberek jelentős része aktív dohányos (82\%) volt (3. ábra), közülük 15\% 0-5 szálat, 23\% 6-10 szálat, 21\% több mint fél doboz és 41\% legalább egy doboz cigarettát szívott el naponta (8. táblázat). Mindenképpen ki 
kell hangsúlyozni, hogy általában nem a boltban vásárolt füstszürős cigarettákat szívják, hanem maguk sodorják - nem ritka, hogy újságpapírba -, a hozzá való dohányt pedig számos esetben az eldobott csikkekből gyűjtik össze. Ez a módja a dohányzásnak feltehetőleg még nagyobb egészségkárositó hatással bír (Shahab et al. 2009).

Az alsó jövedelmi ötödbe tartozó emberek 46\%-a dohányzott rendszeresen. Habár ez az arány csaknem fele a hajléktalanpopulációban mért értéknek, viszont körükben magasabb azoknak az aránya (50\%), akik egy doboz, illetve egy doboz cigarettánál többet fogyasztottak el, továbbá szintén több olyan ember volt, aki 11-15 szálat szívott el (22\%) naponta.

Az átlagpopulációban voltak a legkevesebben az aktív dohányosok (33\%). Nem volt azonban túl nagy eltérés a másik két vizsgált populációhoz hasonlítva a naponta elszívott cigaretták mennyiségében. 46\%-uk minimum egy dobozzal, 22\% legalább fél dobozzal szívott el. Tíz szál vagy annál kevesebb cigarettát az átlagpopuláció 37\%-a, az alsó jövedelmi ötöd 29\%-a, illetve a hajléktalanok 38\%-a szívott el.

\section{3. ábra: Dohányzási szokások a vizsgált populációkban}

Smoking habits in the studied populations

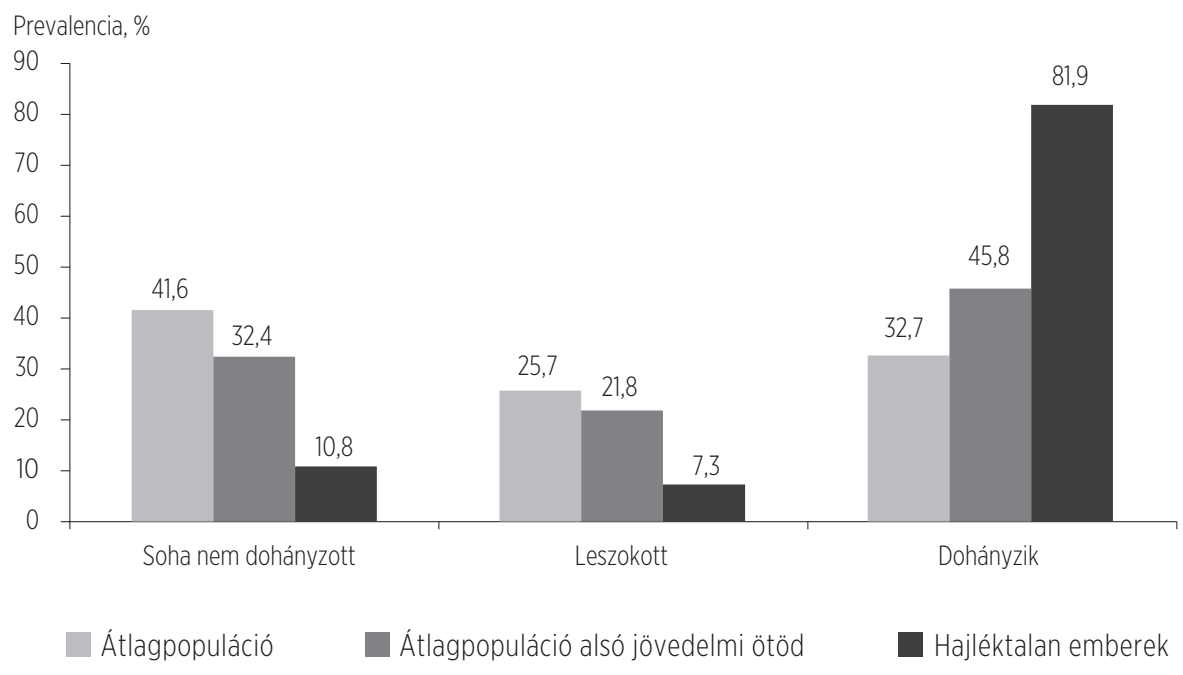

Az átlagpopuláció 42, míg az alsó jövedelmi ötöd 32\%-a saját bevallása szerint sosem dohányzott, továbbá a két populációban 26 , illetve $22 \%$ volt azoknak az aránya, akik már leszoktak a dohányzásról. A felmérésben részt vevő hajléktalan 
emberek csupán 18\%-a volt nem dohányzó, ebből 11\% soha nem dohányzott, 7\%-uk pedig leszokott róla.

8. táblázat: A naponta elszívott cigaretta mennyisége a vizsgált populációkban (aktív dohányosok) Number of cigarettes smoked per day by active smokers

\begin{tabular}{cccc}
$\begin{array}{c}\text { Naponta elszívott cigaretta } \\
\text { mennyisége, szál }\end{array}$ & Átlagpopuláció & $\begin{array}{c}\text { Átlagpopuláció alsó } \\
\text { jövedelmi ötöd }\end{array}$ & Hajléktalan emberek \\
\hline $0-5$ & 9,2 & 7,8 & 15,3 \\
$6-10$ & 23,5 & 20,7 & 22,8 \\
$11-15$ & 21,7 & 22,0 & 20,6 \\
$16-20$ & 31,2 & 32,6 & 23,6 \\
$>20$ & 14,3 & 16,9 & 17,7 \\
\hline
\end{tabular}

A dohányzás mellett az alkoholfogyasztás a másik olyan életmódbeli tényező, amely rendkívül nagy egészségkárosító hatással bír. Az alkohol hatásai közül kiemelendő a központi idegrendszerre kifejtett hatása, túlzott fogyasztása többek között növeli az alkoholos epilepszia, az alkoholos elbutulás, a perifériás neuropátia, továbbá a májzsugorodás, a májrák, a hasnyálmirigy-gyulladás és a szájüregi rákok kialakulásának a kockázatát. A krónikus egészségkárosodások mellett az alkohol fogyasztása a veszélyérzékelő képesség csökkenését vonhatja maga után, ezáltal megnövelve a balesetek rizikóját.

Az alkoholfogyasztási szokásokat a 4. ábrán foglaltuk össze.

A hajléktalan populációban az absztinensek aránya meglepően magas, $43 \%$ volt, ami több mint kétszerese az átlagpopulációra vonatkozó értéknek (21\%), és jóval magasabb az alsó jövedelmi kategóriába tartozó emberek adatainál is (27\%). A hajléktalanok körében alkalmazott kérdőívben nem kérdeztünk rá az alkoholfogyasztási szokások mögöttes okaira, viszont az adatgyűjtést minden helyszínen személyesen végeztük a hajléktalanellátó intézményekben, ami lehetővé tette számunkra az adatrögzítésen túl a személyes életutak megismerését, az egyéni motivációk és igények megértését. Az alkoholfogyasztási szokásokkal kapcsolatban számos alkalommal nyilatkozták azt a felmérés résztvevői, hogy azért nem isznak, mert az alkoholizmus miatt váltak hajléktalanokká, és nem akarnak még mélyebbre süllyedni a hajléktalanságban. Másik lehetséges indok az lehet, hogy az általunk látogatott hajléktalanellátó intézmények egy részét ittas állapotban nem vehetik igénybe. 
4. ábra: Alkoholfogyasztási szokások a vizsgált populációkban

Alcohol consumption habits in the studied populations

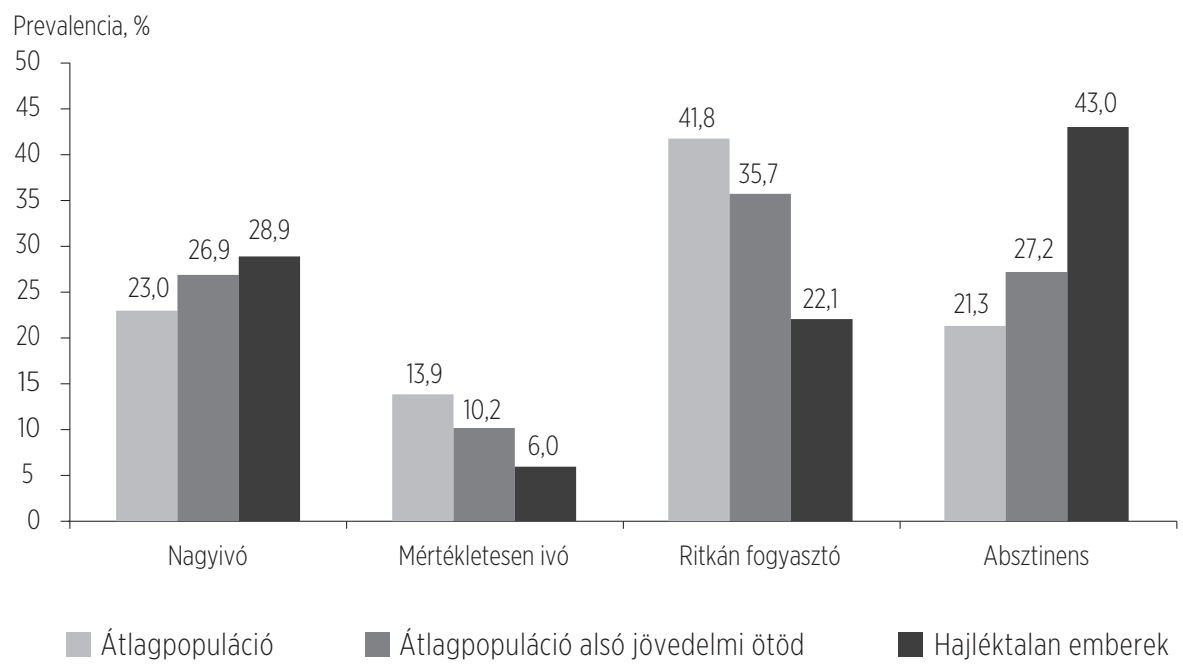

Az átlagpopulációba és az alsó jövedelmi ötödbe tartozók közül legtöbben (42, illetve 36\%) ritkán fogyasztanak alkoholt, ez a hajléktalan emberek 22\%-ra volt jellemző.

Amíg az absztinensek legnagyobb arányban a hajléktalan emberek között voltak jelen, addig a nagyivók prevalenciája is a hajléktalanoknál volt a legmagasabb (29\%), ugyanakkor ez az érték csak 2 százalékponttal haladta meg az átlagpopuláció alsó jövedelmi ötödében és 6 százalékponttal az átlagpopulációban lévő nagyivók arányát. Mértékletesen alkoholt fogyasztók viszonylag kis százalékban voltak jelen a három vizsgált populációban, az átlagpopuláció 14\%-a, az alsó jövedelmi ötödbe tartozók 10\%-a, a hajléktalan emberek 6\%-a tartozott ebbe a kategóriába.

\section{MEGBESZÉLÉS}

A jelen tanulmány fő célja a hajléktalan emberek egészségi állapota jellemzőinek összehasonlítása volt az átlagpopuláció és az átlagpopuláció alsó jövedelmi ötödébe tartozó emberek mutatóival, a hajléktalan emberek specifikus egészség problémáinak azonosítása céljából. Az elemzések során nem és kor szerint standardizáltuk az adatokat, ezért az átlagpopuláció is a hajléktalanok 
megoszlása szerinti jegyeket tükrözi, kiszűrve azt, hogy a három populáció különbségeit az alapvető demográfiai jellemzők eltérései okozzák.

Vizsgálatunk világosan rámutat arra, hogy a hajléktalan emberek - sok más nehézség mellett - nagyon komoly egészségi problémával küszködnek az általános magyarországi lakosság körében mért eredményekhez viszonyítva. Krónikus betegségben 79\%-uk szenved, ez az arány másfélszerese az átlagpopulációs értéknek. Az alacsony háziorvoshoz fordulási gyakoriságból adódóan a betegségeik se monitorozásra, se kezelésre nem kerülnek megfelelően. Tovább rontja a helyzetet a dohányzók rendkívül magas aránya, ami több mint két és félszerese az átlagpopuláció aktív dohányosainak. Közöttük a legmagasabb a nagyivók aránya is, közel háromtizedük ebbe a kategóriába tartozik.

Halálozásukra vonatkozóan jelenleg nincsenek publikált magyarországi adatok, viszont külföldi tanulmányok egyértelműen bizonyítják, hogy drámaian kevesen élik meg körükben az adott ország átlagpopulációjára jellemző születéskor várható élettartamot (Hwang 2000, Stenius - Ayoade et al. 2017). Egy kanadai tanulmányban kimutatták, hogy a 25 éves korban várható élettartam a férfiaknál 13 évvel, nőknél 8 évvel rövidebb volt a hajléktalanszállásokon élők körében az átlagpopulációhoz viszonyítva (Hwang et al. 2009).

A „Február Harmadika Munkacsoport” 2013-ban elvégzett felmérésében a demográfiai helyzetre és jövedelmi viszonyokra vonatkozó kérdéseken túl arra is kíváncsi volt, hogy mit szeretnének, mire van igazából szükségük a magyarországi hajléktalan embereknek. A megkérdezettek 57\%-a (5471 fő) az egészséget választotta a "Ha most leszállna egy angyal, mit kívánna tőle?” kérdésre. „Többnyire azok választották az egészséget, akik egy másik helyen azt írták, az egészségi állapotuk akadályozza őket abban, hogy munkát vállaljanak (2900 akadályozottból 2100-an kérték az angyaltól az egészséget)" (Gurály 2016). Felmerül a kérdés, hogyan valósítható meg, hogy ezeknek az embereknek az egészség mint alapvető emberi jog, ne csak elérhetetlen kivánság legyen.

A hajléktalanná válás és a hajléktalan lét önmagában roppant összetett, soktényezős problémakör, ezért az egészség dimenzióját ezen belül több oldalról célszerü megközelíteni. Az egészséget meghatározó determinánsok közül leginkább a társadalmi-gazdasági státusszal és iskolázottsággal összefüggésbe hozható életmódtényezők felelősek. A társadalmi-gazdasági mutatókat elemezve jól látszik, hogy a hajléktalanok különösen hátrányos helyzetben vannak az átlagpopulációhoz, de még az alsó jövedelmi ötödbe 
tartozó emberekhez képest is. Közel kétharmaduk általános iskolai vagy annál alacsonyabb iskolai végzettségü, 80\%-uknak nincs munkája, és 88\%-uk egyedül él. Ezeknek a drámai mutatóknak a tükrében hatékony egészségnevelési program kidolgozásáról beszélni nagyon nehéz. Az egészségük javítását célzó programok kormányzati intézkedések, népegészségügyi szakemberek és a hajléktalanellátó rendszerben dolgozó szakemberek együttműködésében kellene, hogy megvalósuljon. Egyrészt fontos megtalálni azokat az eszközöket, amelyekkel az alapvető szükségleteik biztonsággal kielégithetők, hogy motiválhatókká váljanak az egészséges(ebb) életmódra, és az egészségükre értékként tudjanak tekinteni. Továbbá olyan kormányzati döntések szükségesek, amelyek a hajléktalanellátó rendszer müködéséhez, bővitéséhez és fejlesztéséhez szükséges forrásokat biztosítja. Nélkülözhetetlen, hogy érdekükben szorosabb és hatékonyabb együttműködés jöjjön létre az egyes ágazatok, kiemelten a szociális, az egészségügyi és a foglalkoztatáspolitikai szektorok között. 


\section{IRODALOM}

Abdelaal, Mahmoud - le Roux, Carel W. - Docherty, Neil G. 2017: Morbidity and mortality associated with obesity. Annals of Translational Medicine, 5(7), 161.

Aron, Laudan - Burt, Martha - Lee, Edgar - Valente, Jesse 2001: Helping America's homeless: emergency shelter or affordable housing? The Urban Institute Press, Washington.

Baggett, Travis P. - O'Connell, James J. - Singer, Daniel E. - Rigotti, Nancy A. 2010: The Unmet Health Care Needs of Homeless Adults: A National Study. American Journal of Public Health, 100(7), 1326-1333.

Busch-Geertsema, Volker - Edgar, William - O'Sullivan, Eoin - Pleace, Nicholas 2010: Homelessness and homeless policies in Europe: lessons from research. FEANTSA European consensus conference on homelessness. FEANTSA, Brussels, http://ec.europa.eu/social/BlobServlet?docld=6442\&langld=en. (Letöltve 2018.09.26.)

Canavan, Réamonn - Barry, Margaret M. - Matanov, Aleksandra - Barros, Henrique

- Gabor, Edina - Greacen, Tim - Holcnerová, Petra - Kluge, Ulrike - Nicaise, Pablo

- Moskalewicz, Jacek - Díaz-Olalla, José Manuel - Straßmayr, Christa - Schene, Aart H. - Soares, Joaquim J. F. - Gaddini, Andrea - Priebe, Stefan 2012: Service provision and barriers to care for homeless people with mental health problems across 14 European capital cities. BMC Health Services Research, 12(1), 222.

Európai lakossági egészségfelmérés 2014: Központi Statisztikai Hivatal ELEF kiadványok, Központi Statisztikai Hivatal, Budapest. http://www.ksh.hu/docs/hun/xftp/stattukor/ elef14.pdf. (Letöltve: 2018.09.26.)

Fazel, Seena - Geddes, John R. - Kushel, Margot 2014: The health of homeless people in high-income countries: descriptive epidemiology, health consequences, and clinical and policy recommendations. Lancet, 384(9953), 1529-1540.

FEANTSA 2017: ETHOS - European Typology of Homelessness and Housing Exclusion. FEANTSA Documents, FEANTSA, Belgium https://www.feantsa.org/download/ ethos2484215748748239888.pdf. (Letöltve 2018.09.26.)

Gelberg, Lillian - Stein, Judith A. - Neumann, Sharlotte G. 1995: Determinants of undernutrition among homeless adults. Public Health Reports,110(4), 448-454.

Gurály Zoltán 2003: A Budapesten élő hajléktalan emberek egészsége. Kapocs, 2(6), 52-57.

Gurály Zoltán 2016: Új otthon, szállótársak és járókelők. Otthontalanul... Tégy az emberért! Dialógusok a hajléktalanságról. BMSZKI, Budapest http://www.bmszki.hu/sites/ default/files/field/uploads/otthontalanul_11_web-1.pdf. (Letöltve: 2018.09.26.)

Gurály Zoltán - Bényei Zoltán - Breitner Péter - Győri Péter - Kovács Ivetta - Mózer Péter - Szabó Andrea 2018: Gyorsjelentés a 2018. évi hajléktalan-adatfelvételröl. Menhely Alapítvány, Budapest. http://menhely.hu/download.php?f=downloads/feb3/2018/F3Gyorsjelentes-2018-handout.pdf. (Letöltve 2018.09.26.)

Győri Péter 2013: Hajléktalanügyi országjelentés. BMSZKI Tanulmányok. BMSZKI, Budapest. http://www.bmszki.hu/sites/default/files/field/uploads/vegso-orszagjelentes2013szallitasra.pdf. (Letöltve 2018.09.26.) 
Hwang, Stephen W. 2000: Mortality among men using homeless shelters in Toronto, Ontario. JAMA, 283(16), 2152-2157.

Hwang, Stephen W. - Wilkins, Russell - Tjepkema, Michael - O'Campo, Patricia J. - Dunn, James R. 2009: Mortality among residents of shelters, rooming houses, and hotels in Canada: 11 year follow-up study. British Medical Journal, 339:b4036.

Hwang, Stephen W. - Ueng, Joanna J. M. - Chiu, Shirley - Kiss, Alex - Tolomiczenko, George - Cowan, Laura - Levinson, Wendy - Redelmeier, Donald A. 2010: Universal health insurance and health care access for homeless persons. American Journal of Public Health, 100, 1454-1461.

Oross Jolán 1995: Hajléktalan emberek egészsége, hajléktalan emberek halála. Periferia füzetek [3]. (1), 2-31.

Papp Ákos 2007: Hajléktalan emberek egészségügyi helyzete Magyarországon. Százlátó üveg Alapitvány Szakmai Anyagok. Százlátó üveg Alapítvány, Budapest. http://www. szazlatouveg.hu/szakmai-anyagok/19. (Letöltve: 2018.09.26.)

Patterson, Michelle L. - Somers, Julien M. - Moniruzzaman, Akm 2012: Prolonged and persistent homelessness: multivariable analyses in a cohort experiencing current homelessness and mental illness in Vancouver, British Columbia. Mental Health Substance Use, 5, 85-101.

Schulze, Matthias B. - Martínez-González, Miguel A. - Fung, Teresa T. - Lichtenstein, Gershoff Alice H. - Forouhi, Nita G. 2018: Food based dietary patterns and chronic disease prevention. British Medical Journal, 361:k2396

Shahab, Lion - West, Robert - McNeill, Ann 2009: A comparison of exposure to carcinogens among roll-your-own and factory-made cigarette smokers. Addiction Biology, 14(3), 315-320.

Stenius-Ayoade, Agnes - Haaramo, Peija - Kautiainen, Hannu - Gissler, Mika - Wahlbeck, Kristian - Eriksson, Johan G. 2017: Mortality and causes of death among homeless in Finland: a 10-year follow-up study. Journal of Epidemiology Community Health, 71, 841-884.

Thompson, Ronald G. - Wall, Melanie M. - Greenstein, Eliana - Grant, Bridget F. - Hasin, Deborah S. 2013: Substance-Use Disorders and Poverty as Prospective Predictors of First-Time Homelessness in the United States. American Journal of Public Health. 103(Suppl 2), S282-S288.

van den Bree, Marianna B. M. - Shelton, Katherine - Bonner, Adrian - Moss, Sebastian Thomas, Hollie - Taylor, Pamela J. 2009: A longitudinal populationbased study of factors in adolescence predicting homelessness in young adulthood. Journal of Adolescent, 45, 571-578.

WHO 1995: Physical status: the use and interpretation of anthropometry. Report of a WHO Expert Committee. World Health Organization technical report series, 854, 1-452.

WHO 2000: Obesity: preventing and managing the global epidemic. Report of a WHO Consultation. WHO Technical Report Series, 894. 


\section{HEALTH OF THE HOMELESS PEOPLE}

\section{ABSTRACT}

Despite the fact that homelessness has risen recently in most parts of Europe and homeless people are vulnerable, there is lack of comprehensive health information on this population. Our aim was to study the health problems of the Hungarian homeless people in comparison with the general population and with the lowest income quintile of the general population (reference populations).

453 individuals were involved in the study from different stages of homelessness according to the European Typology of Homelessness and Housing Exclusion, who used the homeless shelter system. The data was collected by a questionnaire survey. The results were compared with the age and sex standardized data of the European Health Interview Survey 2014 that was carried out in the general Hungarian adult population.

Only $5 \%$ of homeless people reported their health status good compared to the $56 \%$ of the general population and to the $36 \%$ of the lowest income quintile of the general population.

The majority of the homeless people reported to have chronic diseases (79\%), but only $38 \%$ of them visited a GP within one year before the survey. In contrast with that, fewer portion of the general (50\%) and the lowest quintile of the general population (59\%) had chronic diseases and most of them visited GP (76\% and $78 \%$ respectively) within 12 months. Majority of the homeless people were current smoker (82\%), the prevalence was more than double than in the reference population. Surprisingly $43 \%$ of homeless people were reported abstinent, on the other hand, homeless people had also high rate of heavy drinkers (29\%). Of the homeless participants 33\% were classified as overweight and obese, which is half of the prevalence of the general population.

Our study provided evidence of the poor health and health related behavior of homeless people even compared to the poorest quintile of the general population. The poor health of homeless people calls for appropriate public health interventions. Improving access to healthcare and targeted health promotion programs would be the key approaches to improve homeless people's health. 